\title{
Solute Carrier Family 26 Member 6
}

National Cancer Institute

\section{Source}

National Cancer Institute. Solute Carrier Family 26 Member 6. NCI Thesaurus. Code

C114429.

Solute carrier family 26 member 6 (759 aa, $\sim 83 \mathrm{kDa}$ ) is encoded by the human SLC26A6 gene. This protein is involved in chloride exchange activity. 